\title{
Penerapan Senam Selama Hamil dan Efektifitasnya Terhadap Lama Persalinan, Robekan Perineum dan Hasil Luaran Bayi
}

\author{
Sisilia P. Yanuaria, ${ }^{1}$ Tono Djuwantono, ${ }^{2}$ Adjat Sedjati, ${ }^{3}$ Farid Husin, ${ }^{4}$ Herman Susanto, ${ }^{5}$ \\ Hadyana Sukandar ${ }^{6}$ \\ ${ }^{1}$ Mahasiswa Program Studi Magister Kebidanan Fakultas Kedokteran Universitas Padjadjaran \\ ${ }^{2,5}$ Departemen Obstetri dan Ginekologi Fakultas Kedokteran Universitas Padjadjaran \\ ${ }^{3}$ Departemen Ilmu Kesehatan Masyarakat Fakultas Kedokteran Universitas Padjadjaran \\ 4,6 Departemen Epidemiologi dan Bioostastistika Fakultas Kedokteran Universitas Padjadjaran
}

\begin{abstract}
Abstrak
Kurangnya latihan fisik (olahraga) dapat menjadi faktor pencetus timbulnya kecemasan dan ketidaksiapan menjalani kehamilan dan persalinan, tidak dapat beradaptasi terhadap nyeri persalinan serta meningkatkan kesulitan dalam proses persalinan dan kelahiran bayi. Seorang ibu hamil yang mengikuti senam hamil akan lebih bugar dan kuat sehingga mempermudah proses persalinan dan kelahiran bayi.Tujuan penelitian untukmenganalisis perbedaan lama persalinan, derajat robekan perineum dan derajat asfiksia antara ibu hamil yang melakukan senam hamil dan ibu hamil yang tidak melakukan senam hamil.Metode penelitian ini menggunakan metode komparatif cross sectional dan teknik sampling secara consecutive.Subjek penelitian adalah ibu hamil yang datang ke kamar bersalin RS Mayapada dan RSUD Kota Tangerang untuk melahirkan. Jumlah sampel 60 orang, terdiri dari $30 \mathrm{ibu}$ hamil yang melakukan senam hamil (perlakuan) dan 30 yang tidak melakukan senam hamil (kontrol) serta memenuhi kriteria inklusi dan eksklusi. Data diolah dan diuji secara statistik menggunakan program komputerisasi, untuk melihat perbedaan antara kedua kelompok tersebut. Hasil penelitian tentang lama persalinan, didapat perbedaan bermakna antara kelompok perlakuan dan kelompok kontrol $(p=0,007)$. Lama persalinan (kala I dan II) $>600$ menitpada kelompok perlakuan $13,3 \%$ dan kelompok kontrol 43,3\%. Pada robekan perineum, didapat perbedaan bermakna antara kelompok perlakuan dan kelompok kontrol (nilai $p=0,000$ ). Robekan perineum kelompok perlakuan terbanyak derajat 2 (53\%) dan kelompok kontrol terbanyak derajat $3(47 \%)$. Pada derajat asfiksia bayi; menit pertama menunjukkan perbedaan yang bermakna (nilai $p=0,001$ ). Bayi dari kelompok perlakuan terbanyak tidak mengalami asfiksia saat lahir (97\%), dan bayi kelompok kontrol terbanyak tidak asfiksia (57\%) tapi terdapat bayi asfiksia berat (7\%).Simpulan dalam penelitian ini adalah senam hamil merupakan pelayanan prenatal efektif membawa dampak positif terhadap ibu hamil dalam menjalani proses persalinan dan kelahiran bayi, dibanding ibu hamil yang tidak melakukan senam hamil. 96,7\% lama persalinan lebih singkat, $97 \%$ ibu melahirkan mengalami robekan perineum derajat 1-2 dan $97 \%$ bayi baru lahir tidak mengalami asfiksia/asfiksia ringan.
\end{abstract}

Kata Kunci: Asfiksia, lama persalinan, robekan perineum, senam hamil 
Korespondensi: Jl.Eijkman no.38 Bandung Jawa Barat, Hp. 082129180470, e-mail: sisiliaprima@gmail.com

The Application of Exercise During Pregnancy and Effectiveness For Duration of Labor, Perineal Laceration and Infant Outcomes

\begin{abstract}
Lack of physical exercise/sports may be a factor precipitating the onset of anxiety, and unpreparedness through pregnancy and childbirth, cannot adapt to the labor pain and increase the difficulty in labor and childbirth. A pregnant woman who follows the pregnancy exercise will be fitter and stronger, thus simplifying the process of labor and childbirth. The purpose of this study was to analyze the differences of labor duration, perineal laceration degree and the degree of asphyxia among pregnant women who did pregnancy exercise and pregnant women who didn't doing pregnancy exercise. Methods: This was a cross sectional comparative method and sampling techniques were consecutive. The subjects were pregnant women who came to the delivery room at Mayapada Hospital Tangerang and Tangerang District Hospital to give birth. The number of samples are 60 pregnant women, consisting of 30 pregnant women who had pregnancy exercise (treatment) and 30 were not doing pregnancy exercise (control) as well as accordance to the inclusion and exclusion criteria. Furthermore, pregnant women were observed to complete the delivery process. Data were processed and tested statistically using SPSS, to see the level of significance of the difference between the two groups. The results showed there were significant differences between treatment group and control group about the duration of labor $(\mathrm{p}=0.007)$. Duration of labor (first phase and second phase) $>600$ minutes we finded that control group $(43,3 \%)$ highest than treatment group $(13,3 \%)$. So as the degree of perineal laceration, we founded significant differences too $(\mathrm{p}=0.000)$. Perineal laceration highest at treatment group at 2 degrees $(53 \%)$, and in the control group the highest were degree $3(47 \%)$. The degree of asphyxia infants in the first minute showed a significant difference $(\mathrm{p}=0.001)$. Infants of mothers treated group highest had no asphyxia (97\%) and infants of mothers control group highest had no asfiksia too (57\%), but they had severe asphyxia (7\%). Discussion: from this study it can be concluded that the pregnancy exercise is an effective prenatal care had a positive impact on pregnant women in labor and childbirth, compared to pregnant women who are not doing pregnancy exercise. $96,7 \%$ duration of labor was shorter, $97 \%$ of maternal perineal laceration experiencing grade 1-2 and $97 \%$ newborn is not asphyxiated/mild asphyxia.
\end{abstract}

Keywords: Asphyxia, duration of labor, perineal laceration, pregnancy exercise

\section{Pendahuluan}

Kehamilan merupakan periode terjadi perubahan anatomi, fisiologi dan hormonal seorang ibu mengalami penyesuaian sebagai upaya adaptasi antara ibu dan janin.Pada kehamilan pertama, dukungan sosial dari orang sekitar sangat penting bagi kondisi psikologis dan perilaku positif ibu hamil selama kehamilan. Pada kehamilan yang tidak diinginkan atau diharapkan, seorang ibu hamil akan mengalami ketidaknyamanan fisik, depresi yang berkepanjangan, ketidakpuasan terhadap perubahan tubuh, suasana hati yang berlebihan, dan kesulitan menerima perubahan hidup. Pada kehamilan trimester tiga, ibu hamil umumnya merasa bangga dengan kehamilannya dan cemas tentang persalinan dan kelahiran. Ibu hamil merasa khawatir akan kemampuannya dalam melewati proses persalinan. ${ }^{1}$ Pimpinan persalinan sangat menentukan jalannya proses persalinan, khususnya kerjasama dengan pasien sehingga tercapai resultante yang memuaskan kedua belah pihak dengan hasil akhir well born baby dan well healthy mother, sebagai titik awal upaya peningkatan sumber daya manusia. ${ }^{2}$

Persalinan terbagi menjadi persalinan normal dan persalinan dengan distosia.Persalinan normal yaitu persalinan yang berlangsung dengan kekuatan sendiri, serta menunjukan hasil kerjasama dari power, 
passage, passenger (3P) yang berakhir dengan persalinan spontan, belakang kepala, aterm dan hidup. Persalinan dengan cara tersebut merupakan persalinan yang diharapkan karena berlangsung secara fisiologis. Persalinan distosia adalah proses persalinan yang menyimpang dari persalinan eutosia yang disebabkan oleh ketidakserasian antara ketiga komponen penting (3P) sehingga menimbulkan kesulitan jalannya persalinan. Kejadian distosia pada primigravida berkisar antara $4-8 \%$, sedangkan multigravida $2-4 \%$. $^{2}$

Selain ketiga komponen tersebut diatas, proses persalinan juga ditentukan oleh kondisi psikologis seorang ibu (psyche). Bagi ibu primipara, melahirkan merupakan pengalaman pertama, unik dan berbeda antara setiap individu. Rasa nyeri menjelang persalinan merupakan proses yang alamiah. ${ }^{1}$ Read (1944), mengemukakan bahwa rasa sakit disebabkan oleh ketegangan "emosi" menjelang persalinan, karena terbelenggu oleh ketakutan yang menonjol. ${ }^{2}$ Rasa cemas yang berkepanjangan akan memengaruhi kontraksi uterus sehingga mengganggu proses persalinan. $^{3}$

Upaya mengurangi rasa sakit tersebut ditemukan oleh Lamaze (1940) yang mendukung teori Read (1944) yaitu gagasan psikoprofilaksis, yang menekankan untuk menanamkan pengertian persalinan bahwa persalinan yang disertai rasa sakit merupakan proses alamiah. Dengan demikian diharapkan secara psikologis seorang parturien, telah siap menderita atau menerima rasa sakit yang membahagiakan untuk menyongsong kelahiran bayi sebagai buah cintanya. ${ }^{2}$ Dukungan selama proses persalinan dan kelahiran sangat dibutuhkan. Respon psikologis maternal yang positif ini memungkinkan wanita untuk mengatasi nyeri dan ketakutan serta memenuhi kebutuhan fisik selama persalinan dan kelahiran. ${ }^{1}$

Hasil penelitian terdahulu, menunjukkan ada perbedaan yang signifikan antara perubahan tingkat kecemasan menghadapi persalinan pada kelompok perlakuan dan kelompok kontrol.Adapun pengaruh pemberian perlakuan senam hamil terlihat pada kelompok perlakuan, yaitu adanya penurunan rerata skor kecemasan yang lebih besar daripada kelompok kontrol. Mereka tidak merasakan suatu ketegangan yang biasa timbul sehingga tubuhnya dapat beristirahat dan tidak mudah lelah. ${ }^{4}$

Hasil penelitian lain dengan metode randomized controlled trial (RCT), menunjukkan bahwa latihan otot dasar panggul selama kehamilan dan persalinan dapat mencegah inkontinensia urin 1 dari 6 ibu hamil dan 1 dari 8 ibu setelah melahirkan. Selain itu, kekuatan otot dasar panggul semakin meningkat pada kehamilan usia 36 minggu sampai dengan 3 bulan setelah melahirkan. Pada penelitiannya juga ditemukan bahwa insiden persalinan normal dan ekstraksi vakum lebih tinggi pada kelompok perlakuan sedangkan ekstraksi forsep dan seksio sesaria lebih tinggi pada kelompok kontrol.Namun secara statistik, tidak ada perbedaan yang signifikan antara kelompok kontrol dan kelompok perlakuan. Selain itu, tidak terdapat adanya efek samping negatif dari latihan otot dasar panggul. ${ }^{5}$

Selain itu, hasil penelitian pada primipara Norwegia didapatkan bahwa latihan otot dasar panggul selama kehamilan dengan frekuensi $<1 \mathrm{kali} /$ minggu memiliki risiko yang lebih besar untuk mengalami robekan perineum derajat tiga dan empat, ekstraksi vakum/forsep dan seksio sesarea serta episiotomi; dibanding yang melakukan latihan 3 kali/minggu. ${ }^{6}$ Penelitian lain menunjukan bahwa ibu hamil yang tidak melakukan aktifitas fisik sebelum hamil lebih tinggi risiko terjadinya laserasi perineum dalam persalinan $\mathrm{OR}=6.1$ (1.622.9). ${ }^{7}$

Proses persalinan dimulai sejak his teratur sampai kala dua untuk multigravida memerlukan waktu sekitar 8-10 jam sedangkan primigravida memerlukan waktu lebih lama yaitu 10-12 jam. ${ }^{2}$ Persalinan lama, yaitu jika fase laten kala I lebih dari 8 jam (prolonged latent phase), dilatasi serviks di kanan garis waspada pada persalinan fase aktif (prolonged active phase) atau persalinan lebih dari 12 jam atau lebih bayi belum lahir. Salah satu penyebabnya adalah inadekuat kontraksi uterus (inersia uteri) termasuk serviks yang kaku terutama pada primigravida dan wanita yang dependen, cemas dan ketakutan atau kelelahan.Komplikasi yang dapat timbul antara lain trauma jalan lahir dan asfiksia bayi baru lahir. ${ }^{8}$ Pemanjangan fase laten maupun fase aktif meninggikan kematian perinatal. ${ }^{9}$ 
Kondisi/kebugaran bayi baru lahir dapat dinilai dari ada atau tidaknya kejadian asfiksia. Asfiksia adalah kegagalan bayi bernapas secara spontan dan teratur segera setelah lahir. ${ }^{10}$ Diperkirakan $10 \%$ bayi baru lahir membutuhkan bantuan untuk bernapas saat lahir dan $1 \%$ saja yang membutuhkan resusitasi yang ekstensif. ${ }^{11}$ Penilaian dapat 2 (dua) kali yaitu penilaian awal dan skor APGAR. ${ }^{8}$ Penilaian awal saat lahir harus dilakukan pada semua bayi; apakah bayi cukup bulan, apakah bayi menangis atau bernapas, dan apakah tonus otot bayi baik. Jika bayi lahir cukup bulan, menangis dan tonus ototnya baik menunjukkan bayi tidak asfiksia. Bayi yang tidak memenuhi kriteria tersebut, perlu dilakukan tindakan resusitasi. ${ }^{8,11}$

Penilaian APGAR adalah metode penilaian dini yang digunakan untuk mengkaji kondisi bayi setelah lahir dengan skor $0,1,2$ untuk 5 (lima) tanda klinis yaitu denyut jantung, pernapasan, refleks terhadap rangsangan, tonus otot dan warna kulit. Penentuan tingkatan (grading) ini dilakukan 1 (satu) menit setelah lahir dan diulang setelah 5 (lima) menit. Bayi dalam kondisi normal jika ada dalam kisaran 7-10.Skor 4-6 menunjukan depresi pernapasan (asfikisa) ringan sampai sedang. Jika skor APGAR 0-3, bayi mengalami aspiksia berat. ${ }^{12}$ Penelitian menunjukkan bahwa APGAR skor pada 5 menit pertama $<7$ berhubungan dengan meningkatnya prevalensi gangguan saraf $(6,6 \%)$ dan rendahnya fungsi kognitif $(9,9 \%)$. Sedangkan pada ibu usia $\leq 20$ tahun, prevalensi rendahnya fungsi kognitif meningkat $15 \%-35 \%$. APGAR skor $<7$ pada menit ke lima berhubungan dengan prevalensi gangguan saraf dan fungsi kognitif di masa dewasa. ${ }^{13}$

Hasil penelitian menemukan bahwa ibu hamil yang berolahraga selama hamil akan mengalami onset persalinan lebih awal dibandingkan wanita hamil yang tidak olahraga selama hamil. Mereka yang berolahraga memiliki onset persalinan ratarata 7 hari lebih awal dari yang tidak.Selain itu, semua wanita yang melakukan olahraga selama hamil menghasilkan kelahiran hidup, sebagian besar bayi (98\%) nilai APGARnya normal dan tidak ada bayi yang memerlukan perawatan khusus. ${ }^{14}$.
Banyak pilihan untuk olahraga selama hamil.Senam hamil merupakan salah satu alternatif yang dapat dipilih oleh ibu hamil untuk menjaga kebugaran tubuhnya sehingga dapat melewati masa kehamilan dan persalinan dengan aman dan selamat.Latihan senam khusus wanita hamil ini merupakan latihan fisik dan psikis untuk mempersiapkan wanita tersebut menghadapi persalinan.

Dengan mengikuti dan melakukan senam hamil secara teratur dan intensif di rumah sakit dapat meningkatkan relaksasi otot dasar panggul, uterus berkontraksi dengan baik, ritmis dan kuat sehingga bayi dengan mudah melalui jalan lahir. Senam hamil dapat menanamkan kepercayaan pada diri sendiri dan kepada penolong. ${ }^{15}$

Penelitian sebelumnya menunjukan bahwa program latihan fisik selama hamil trimester pertama, kedua dan ketiga dapat meningkatkan persepsi ibu maternal tentang status kesehatannya. Persepsi ibu meningkat dengan sangat baik sebesar $54,5 \%$ pada kelompok perlakuan sedangkan pada kelompok kontrol hanya sebesar 27,3\% ( $\mathrm{p}=0,03$, bermakna). Persentase ibu dalam kelompok perlakuan yang mengalami persalinan normal lebih tinggi dibandingkan kelompok kontrol. Begitupula dengan kejadian robekan jalan lahir, persentase lebih tinggi pada kelompok kontrol. ${ }^{16}$

\section{Metode}

Penelitian ini dilakukan dengan rancangan penelitian komparatif cross sectional. Subjek penelitian adalah ibu bersalin di Rumah Sakit yang berada di Wilayah Kecamatan Cipondoh Kota Tangerang yaitu RS Mayapada dan RSUD Kota Tangerang pada bulan Juni sampai dengan bulan Agustus 2014. Jumlah responden penelitian 60 orang yang terbagi menjadi kelompok ibu hamil yang melakukan senam hamil (perlakuan) dan kelompok ibu hamil yang tidak melakukan senam hamil (kontrol).Sampel dipilih secara consecutive (urutan datang ibu bersalin yang memenuhi kriteria inklusi dan eksklusi). ${ }^{17}$ Kriteria inklusi, yaitu primigravida, inpartu dengan janin tunggal. Usia ibu antara 20-35 tahun, usia kehamilan 37-40 minggu sesuai Hari Pertama Haid Terakhir (HPHT), pemantauan persalinan dicatat secara lengkap dalam partograf, tidak ada riwayat komplikasi 
kehamilan yang menyertai seperti ketuban pecah dini, pertumbuhan janin terhambat; tidak ada riwayat penyakit degeneratif yang menyertai seperti penyakit jantung, asma, diabetes, penyakit paru-paru serta persalinan spontan. Pengumpulan data melalui wawancara, observasi dan analisis dokumen terdiri dari satu kelompok ibu inpartu yang mengikuti senam hamil (perlakuan) sebanyak 30 orang dan satu kelompok ibu inpartu yang tidak mengikuti senam hamil (kontrol) sebanyak 30 orang.Data ibu inpartu yang diambil adalah pada bulan Juni hinggaAgustus 2014. Data dianalisis dengan teknik kuantitatif menggunakan program komputer.

\section{Hasil \\ Karakteristik Subjek Penelitian}

Gambaran karakteristik responden penelitian ini meliputi: umur, pendidikan, pekerjaan dan berat badan bayi saat lahir; seperti tabel di bawah.

Tabel 1. Karakteristik responden

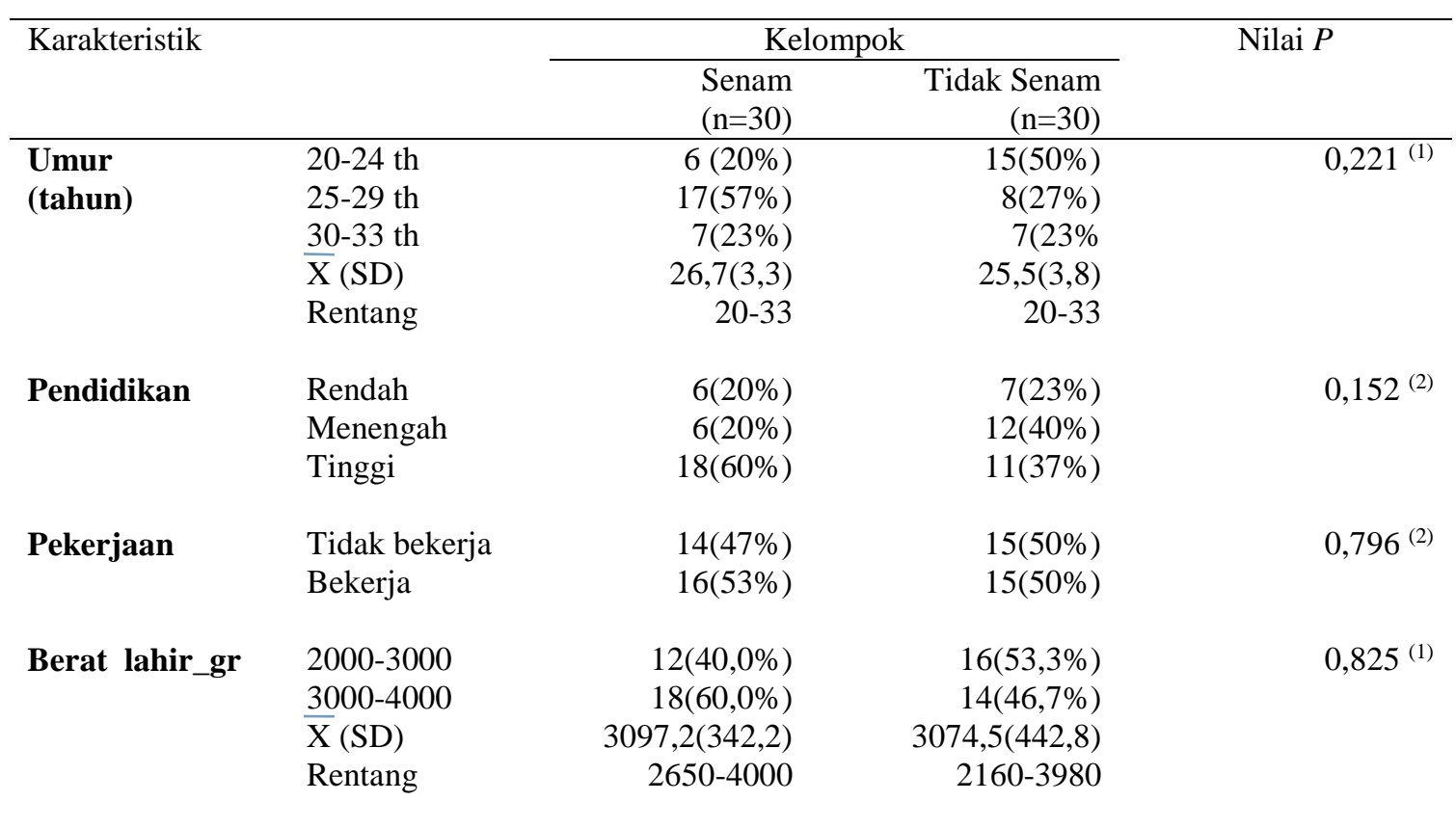

Keterangan:

(1) berdasarkan uji T-test

(2)berdasarkan uji ChiKuadrat

Tabel 1 di atas menunjukan bahwa responden dari kelompok senam hamil terbanyak adalah ibu bersalin yang berumur 25-29 tahun (57\%) dengan rerata umur 26,7 tahun. Sedangkan pada kelompok tidak senam hamil tertinggi ada pada kelompok umur 2024 tahun (50\%) dengan rerata 25,5 tahun. Secara keseluruhan, responden penelitian terbanyak adalah ibu bersalin pada umur 2529 tahun (42\%) dengan rentang usia 20-33 tahun. Hasil analisis menunjukkan tidak ada perbedaan yang signifikan antara umur ibu dari kelompok yang melakukan senam dan tidak senam $(p>0,05)$.
Berdasarkan pendidikan, responden kelompok senam terbanyak adalah ibu bersalin dengan tingkat pendidikan tinggi (60\%).Sedangkan pada kelompok tidak senam hamil tertinggi ada pada kelompok pendidikan menengah (40\%).Secara keseluruhan, responden penelitian terbanyak adalah ibu bersalin dengan pendidikan tinggi (48\%). Hasil analisis menunjukkan tidak ada perbedaan yang signifikan pada pendidikan antara ibu dari kelompok yang melakukan senam dan tidak senam $(p>0,05)$.

Berdasarkan pekerjaan, responden kelompok senam terbanyak adalah ibu bersalin yang bekerja (53\%). Sedangkan pada 
kelompok tidak senam hamil persentase sama antara ibu hamil pada kelompok tidak bekerja $(50 \%)$ dan bekerja (50\%). Secara keseluruhan, persentase responden penelitian terbanyak adalah yang bekerja (52\%). Hasil analisis menunjukkan tidak ada perbedaan yang signifikan pada pekerjaan antara kelompok yang melakukan senam dan tidak senam $(p>0,05)$.

Berdasarkan berat bayi saat lahir; pada kelompok senam hamil terbanyak adalah bayi dengan berat lahir 3000-4000 gram (60\%) dan rentang berat lahir antara 2650-4000 gram dan pada kelompok tidak senam hamil terbanyak adalah bayi dengan berat lahir 2000-3000 gram $(53,3 \%)$ dan rentang berat lahir antara 2160-3980 gram. Rerata berat bayi saat lahir adalah 3097 gram lebih berat dibandingkan kelompok tidak senam hamil yaitu 3074 gram.Namun hasil analisis menunjukkan tidak ada perbedaan yang signifikan berat badan bayi saat lahir antara kelompok yang melakukan senam dan tidak senam $(p>0,05)$.

Hasil analisis statistik terhadap data umur ibu, pendidikan, pekerjaan dan berat bayi saat lahir di atas menunjukkan nilai yang tidak signifikan antara kelompok ibu hamil yang melakukan senam hamil dan tidak $(p>0,05)$. Dengan demikian data ini layak untuk dibandingkan.

\section{Perbedaan Lama persalinan, derajat robekan perineum dan asfiksia}

Perbedaan antara lama persalinan, robekan perineum dan asfiksia dapat dilihat pada tabel 2 di bawah ini.

Tabel 2. Perbedaan lama persalinan, derajat robekan perineum, dan derajat asfiksia bayi

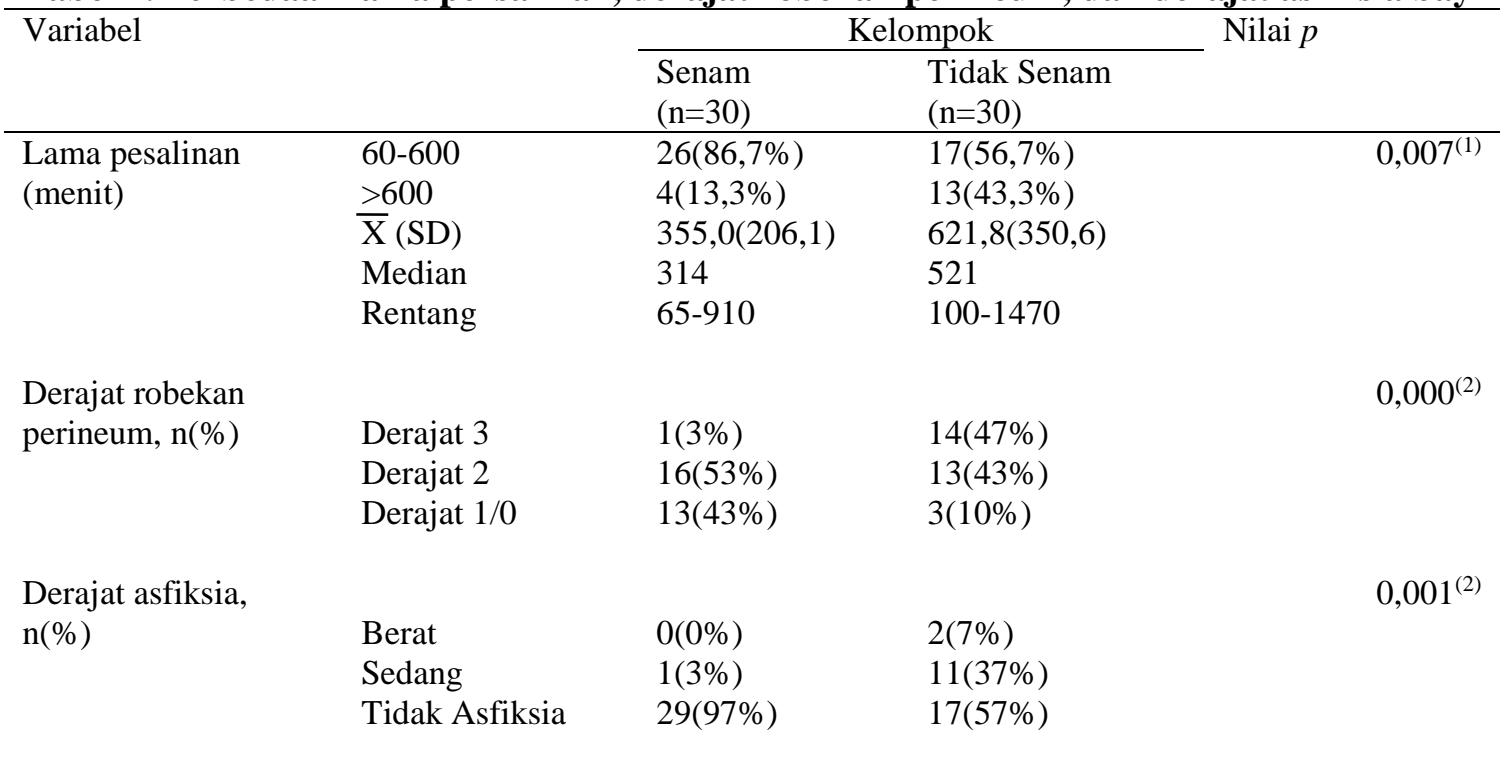

\footnotetext{
Keterangan:

(1)berdasarkan uji Mann-Whitney U.

(2) berdasarkan uji Chi kuadrat
}

Tabel 2 di atas menunjukkan terdapat perbedaan lama persalinan pada antara ibu hamil yang melakukan senam hamil dan tidak melakukan senam hamil. Secara statistik perbedaan ini bermakna dengan nilai $p=0,007$. Perentase lama persalinan $\leq 600$ menit $(10 \mathrm{jam})$ terbanyak pada kelompok senam hamil $(86,7 \%)$, sedangkan $>600$ menit terbanyak pada kelompok tidak senam hamil $(43.3 \%)$. Ibu hamil yang melakukan senam hamil; robekan perineum paling banyak terjadi pada derajat $2(53 \%)$ sedangkan pada ibu hamil yang tidak melakukan senam hamil, terbanyak adalah robekan derajat $3(47 \%)$. Secara statistik, perbedaan ini bermakna dengan nilai $p=0,000$.

Bayi yang dilahirkan dari ibu hamil yang melakukan senam hamil, terbanyak tidak mengalami asfiksia $(97 \%)$ pada menit pertama kelahirannya.Sedangkan pada ibu hamil yang tidak melakukan senam hamil terbanyak adalah tidak mengalami asfiksia namun dengan presentasi yang lebih rendah (57\%).Pada kelompok ibu hamil yang tidak 
melakukan senam hamil, terdapat bayi yang mengalami asfiksia berat dan asfiksia sedang dengan persentase yang lebih tinggi dibandingkan yang melakukan senam hamil.Secara statistik, perbedaan ini sangat bermakna, dengan nilai $p=0,001$.

\section{Diskusi}

\section{Karakteristik Subjek Penelitian}

Karakteristik

diperbandingkan terlebih dahulu untuk mengetahui bahwa kelompok pada penelitian ini homogen. Kedua kelompok pada penelitian ini layak diperbandingkan karena tidak terdapat perbedaan yang bermakna antara kedua kelompok (nilai p>0,05). Karakteristik subjek yang diteliti meliputi umur, pendidikan, pekerjaan dan berat badan lahir.

a. Umur

Hasil penelitian ini umur responden minimal adalah 20 tahun dan maksimal adalah 33 tahun, jadi termasuk dalam umur reproduksi ideal.Dalam penelitian ini tidak diketemukan perbedaan yang signifikan antara umur ibu dengan robekan jalan lahir.

Umur yang dapat menyebabkan robekan perineum pada primipara adalah umur $<20$ tahun dan $>35$ tahun.Pada umur $<20$ tahun, fungsi organ reproduksi belum sempurna.Perineum masih kaku serta kondisi kejiwaan belum cukup mampu untuk menerima kehamilan dan persalinan.pada umur >35 tahun, fungsi organ, mulai berkurang serta elastisitas vagina juga menurun menyebabkan meningkatnya risiko. ${ }^{18,19}$

b. Pendidikan

Pendidikan antara kedua kelompok penelitian berdasarkan uji statistik adalah tidak bermakna $(p>0,05)$. Dalam penelitian ini, responden umumnya dengan tingkat pendidikan tinggi, meskipun persentase kelompok senam lebih besar dibandingkan kelompok tidak senam.Tingkat pendidikan berhubungan dengan pengetahuan wanita hamil terhadap kesehatan kehamilannya termasuk kunjungan antenatal yang teratur. Wanita hamil yang sering melakukan kunjungan antenatal selama hamil akan melakukan hal-hal yang akan memperbaiki dirinya sehingga hasil akhir kehamilannya diharapkan akan lahir dengan baik dan normal. ${ }^{14}$

Pengetahuan merupakan dasar untuk pembentukan tingkatan ranah kognitif. Seorang ibu hamil dengan tingkatan pendidikan lebih tinggi maka lebih mengerti manfaat senam hamil dan pengaruhnya terhadap proses persalinan. Pendidikan juga berfungsi sebagai media atau sarana untuk menyediakan kondisi sosiopsikologis sedemikian rupa sehingga individu tersebut berperilaku sesuai dengan norma hidup yang berlaku.

Pada dasarnya seorang ibu yang melakukan antenatal secara teratur sesuai dengan standar serta sadar untuk mengikuti senam hamil juga dipengaruhi perilakunya.Selain itu dipengaruhi ketersediaan fasilitas pendukung untuk kegiatan senam hamil. Layanan senam hamil di RS wilayah Kecamatan Cipondoh hanya dilakukan 2 dari 3 RS yang ada, yaitu RS Mayapada dan RS Usada Insani (RS swasta), sedangkan RSUD Kota Tangerang belum ada program senam hamil. Hal ini mungkin menjadi penyebab tidak semua ibu hamil dengan pendidikan tinggi dlam penelitian ini, mengikuti kegiatan senam hamil.

Kecenderungan ibu hamil yang mengikuti senam hamil didasari oleh pengetahuan ibu hamil yang berhubungan dengan kehamilannya dan proses persalinan, sehingga diharapkan ibu hamil yang mengikuti senam hamil secara teratur diharapkan akan melahirkan dengan normal untuk menghilangkan kecemasan dan ketakutan pada saat proses persalinan pertama. ${ }^{18}$

c. Pekerjaan

Hasil analisis menyatakan bahwa tidak ada perbedaan secara signifikan antara responden antara kelompok senam dan tidak senam $(p>0,05)$. Pekerjaan berhubungan dengan gerakan fisik, sehingga semakin sering ibu beraktifitas semakin baik bagi kebugaran tubuhnya.

Sekitar 40\% wanita hamil di Amerika Serikat melakukan senam hamil.mereka percaya bahwa latihan fisik selama hamil akan memudahkan proses persalinan. sedangkan penelitian di Columbia pada 557 wanita hamil menyimpulkan bahwa semakin aktif kegiatan fisik, wanita hamil semakin mudah dalam proses persalinan. kebugaran jasmani adalah 
kemampuan seseorang untuk menunaikan tugas sehari-hari dengan mudah tanpa lelah berlebihan dan masih mencapai cadangan tenaga untuk menikmati waktu senggang dan untuk keperluan mendadak. ${ }^{18,20}$

\section{d. Berat badan bayi saat lahir}

Pada penelitian ini ditemukan bahwa berat badan bayi saat lahir pada kelompok senam hamil cenderung lebih besar dibandingkan kelompok tidak senam hamil, meskipun analisis menunjukkan tidak ada perbedaan yang signifikan antara kedua kelompok tersebut $(p>0,05)$.

Pada beberapa penelitian didapatkan bahwa berat janin yang lahir dari wanita yang melakukan senam hamil/olahraga selama kehamilannya lebih berat dibandingkan yang tidak senam/olahraga. Penelitian yang dilakukan di Malibu menemukan bahwa ibu hamil dengan tinggi badan $\geq 1,65 \mathrm{~m}$ yang melakukan senam/olahraga selama hamil melahirkan bayi yang lebih berat dibandingkan ibu hamil dengan berat badan $<1,65 \mathrm{~m} \cdot{ }^{20}$

Olahraga dapat meningkatkan aliran darah ke uterus, yang merupakan jalan terpenting bagi suplai nutrien, oksigen dan metabolisme janin.Terdapat hubungan yang positif antara berat plasenta dengan berat badan lahir. Wanita hamil yang melakukan latihan selama hamil akan memiliki plasenta yang lebih berat akibat meningkatnya plasenta blood flow. Data ini juga didukung oleh penelitian Clapp yang mendapatkan bahwa olahraga rekreasional meningkatkan pertumbuhan plasenta pada pertengahan semester kehamilan dan mengakibatkan janin lebih berat. ${ }^{14}$

Kelemahan penelitian ini adalah peneliti tidak memantau secara langsung frekuensi senam yang dilakukan ibu hamil seperti yang diharapkan yaitu minimal 3 kali dalam seminggu.Setelah latihan di rumah sakit penelitipun tidak memantau latihan lanjutan yang dilakukan oleh responden di rumahnya. Peneliti hanya melakukan wawancara tentang frekuensi mengikuti senam hamil dan mengambil data sekunder melalui buku register (kohort restrospektif). Sedangkan outcome senam hamil diambil pada saat ibu hamil masuk rumah sakit untuk melahirkan.

\section{Lama Persalinan}

Persalinan pada primigravida memerlukan waktu lebih lama yaitu 10-12 jam. Fase yang lebih panjang dari 12 jam merupakan keadaan abnormal yang disebut persalinan lama. Kerja uterus yang tidak efisien akibat kelelahan miometrium sering menyertai proses ini. $^{2}$ Lama persalinan dipengaruhi oleh banyak faktor, salah satunya adalah power. Power di sini adalah kontraksi uterus dan kekuatan ibu mengedan. ${ }^{14}$ Selain power, lama persalinan berhubungan dengan kondisi psikologis seorang ibu hamil.persalinan yang lebih lama dihubungkan dengan kadar katekolamin yang lebih tinggi, yang berhubungan dengan kecemasan pasien. ${ }^{1,2}$

Penelitian kohort retrospektif terhadap ibu bersalin nulipara di Amerika, ditemukan bahwa persalinan kala II lama terjadi pada ibu dengan epidural lebih dari 3 jam. Persalinan lama juga berhubungan dengan meningkatnya korioamnionitis dan robekan perineum derajat 3 dan 4. Pada neonatus ditemukan adanya sepsis, asfiksia dan meningkatnya mortalitas perinatal. ${ }^{21}$ Penelitian lain menunjukan bahwa persalinan lama berhubungan dengan penurunan saturasi oksigen janin. ${ }^{23}$

Olahraga selama hamil akan menguntungkan baik fisik dan psikologik, mengingat perasaan takut dan cemas dalam menghadapi kehamilan dan persalinan dapat menimbulkan ketegangan jiwa dan fisik, yang dapat menyebabkan kekakuan otot-otot persendian sehingga persalinan berjalan tidak wajar. Senam hamil merupakan salah satu bentuk olahraga guna membantu wanita hamil memperoleh power yang baik sehingga memperlancar proses persalinannya dan menuntun wanita hamil ke persalinan fisiologis. ${ }^{14}$ Gerakan senam umumnya merupakan gerakan relaksasi. Diharapkan stres menjalani kehamilan dan menghadapi persalinan akan berkurang, karena di sini diajarkan cara pernafasan dan cara mengejan yang benar. ${ }^{4,14}$

Salah satu keuntungan fisik senam hamil adalah meningkatkan dan memperbaiki sistem peredaran darah, khususnya ke otot-otot sehingga meningkatkan kekuatan dan tonus otot serta memperbaiki pertumbuhan otot-otot uterus. Pertumbuhan otot uterus yang optimal akan menyebabkan kontraksi uterus lebih optimal dan terkoordinasi di saat persalinan. 
Senam atau latihan selama hamil memberikan efek positif terhadap pembukaan serviks dan aktifitas uterus yang terkoordinasi saat persalinan sehingga lama persalinan lebih singkat. ${ }^{14}$

Penelitian mengenai efektifitas senam hamil terhadap kecemasan ibu hamil, menunjukan perbedaan yang signifikan antara perubahan tingkat kecemasan kelompok eksperimen dan kelompok kontrol dengan nilai $p=0,034(p<0,05)$. Pengaruh pemberian perlakuan senam hamil terlihat pada kelompok eksperimen, yaitu adanya penurunan rerata skor kecemasan yang lebih besar daripada kelompok kontrol. Ibu hamil yang rutin melakukan senam hamil akan memberi kontribusi yang besar untuk melancarkan proses persalinan. ${ }^{4}$

Penelitian di Yogyakarta terhadap primigravida; didapatkan bahwa kejadian partus lama lebih kecil secara bermakna $(\mathrm{p}=0,031)$. Secara statistik $\mathrm{RR}=0,125$; artinya risiko partus lama pada ibu yang melakukan senam hamil 0,125 kali dibandingkan dengan ibu yang tidak melakukan senam hamil. Penelitian di Balipun menemukan hal yang sama bahwa insiden partus lama pada kelompok senam hamil secara statistik lebih kecil dibandingkan kelompok yang tidak senam hamil $(p=0,031) .{ }^{14}$

Dalam penelitian ini, ditemukan bahwa lama persalinan pada kelompok ibu hamil yang tidak melakukan senam hamil lebih lama dibandingkan dengan lama persalinan kelompok ibu hamil yang tidak melakukan senam hamil. Secara statistik, perbedaan ini sangat bermakna $(p=0,007)$. Hal ini menunjukan bahwa senam selama hamil efektif mempersingkat lama persalinan pada primigravida.

Sejalan dengan penelitian ini, beberapa penelitian juga lain melaporkan bahwa ibu hamil yang aktif selama kehamilan lebih pendek lama persalinannya dibandingkan dengan ibu hamil yang tidak melakukan aktifitas fisik ataupun berolahraga. Lama persalinan ini termasuk persalinan kala satu dan kala dua. Ibu hamil yang melakukan senam memberikan efek positif terhadap kematangan serviks dan aktifitas uterus lebih terkoordinasi. Tetapi secara statistik, tidak ada perbedaan bermakna lama persalinan antara ibu yang melakukan senam dan tidak. ${ }^{18}$

\section{Robekan Perineum}

Kelahiran pervaginam merupakan penyebab kerusakan otot, neuromuscular dan jaringan penunjang. Robekan/trauma perineum dapat bersumber dari persalinan spontan atau episiotomi untuk melebarkan introitus vagina. ${ }^{18}$ Dalam penelitian ini ditemukan bahwa robekan perineum yang bersumber dari episiotomi terbanyak terjadi pada ibu hamil yang tidak melakukan senam hamil dan robekan spontan terbanyak pada kelompok ibu hamil yang melakukan senam hamil.

Selama proses persalinan normal, laserasi perineum dan vagina dapat disebabkan oleh pengeluaran kepala yang mendadak dan cepat, ukuran bayi baru lahir yang berlebihan dan jaringan ibu yang mudah robek. Laserasi derajat satu dan dua sangat umum terjadi pada primigravida; insidennya yang tinggi merupakan salah satu rasional untuk penggunaan episiotomi. ${ }^{3}$ Selain itu, robekan perineum dapat disebabkan oleh meningkatnya umur ibu, persalinan pertama, lama kala dua. ${ }^{23}$ Salah satu indikasi episiotomi yaitu dilakukan pada hampir semua primipravida, jika dijumpai crowning kepala tidak seimbang dengan elastisitas perineum dan pada kondisi distosia yang disebabkan oleh kurangnya elastisitas perineum. ${ }^{2}$

Penelitian lain menunjukan latihan senam pada ibu hamil menurunkan terjadinya laserasi perineum selama persalinan. Selain itu, frekuensi episiotomi lebih rendah pada kelompok senam yang memiliki struktur program latihan otot dasar panggul untuk kelompok ibu hamil umur 20-36 tahun. Ibu hamil yang tidak aktif berolahraga juga berhubungan dengan buruknya fungsi dari jaringan penunjang otot pelvis, mengurangi kekuatan rotasi dan kala dua persalinan menjadi lebih lama. ${ }^{18}$

Sebuah penelitian di United State menunjukan bahwa wanita yang pertama kali melahirkan memiliki risiko mengalami robekan perineum, terutama wanita dengan pendidikan tinggi, mengedan valsava dan berhubungan dengan berat lahir bayi. Teknik persalinan yang tidak terburu-buru dan terkontrol dapat mengurangi trauma jalan lahir. ${ }^{24}$ 
Penelitian tersebut sejalan dengan hasil penelitian ini.Pada penelitian ini ditemukan bahwa robekan perineum pada kelompok ibu yang melakukan senam terbanyak pada kelompok pendidikan tinggi. Secara statistik, korelasi ini bermakna $(p<0,05)$. Sebaliknya, pada kelompok ibu hamil yang tidak melakukan senam, terbanyak pada kelompok dengan tingkatan pendidikan menengah dan secara statistik hubungan ini bermakna $(p<0,05)$.

Dalam penelitian ini ditemukan pula $90 \%$ ibu hamil yang tidak melakukan senam hamil mengalami robekan perineum derajat 2 dan 3 , lebih tinggi dibandingkan dengan yang melakukan senam hamil (56\%). Secara statistik, perbedaan ini bermakna $(p=0,000)$.

Sebuah penelitian kohort prospektif di Oslo terhadap ibu bersalin yang tidak berolahraga selama hamil, ternyata berhubungan dengan terjadinya laserasi perineum. Ibu hamil yang tidak berolahraga meningkatkan risiko terjadinya robekan perineum pada saat persalinan normal. ${ }^{25}$ Penelitian kohort lainnya yang dilakukan terhadap ibu primigravida di Norwegia menunjukan bahwa tidak ada hubungan antara latihan otot dasar panggul selama hamil dengan laserasi perineum tingkat tiga dan empat. $^{21}$

\section{Asfiksia Bayi Baru Lahir}

Salah satu keuntungan fisik senam hamil adalah memperlancar dan memperbaiki peredaran darah sehingga dapat meningkatkan sirkulasi uteroplasenta yang mengakibatkan pertumbuhan dan perkembangan janin intra uterin menjadi lebih baik.Selama mengikuti senam hamil, tidak terjadi peningkatan aktifitas uterus sehingga aman untuk perkembangan bayi.Selain itu, tidak ada data bahwa latihan teratur selama kehamilan dihubungkan dengan kematian janin dalam rahim. Sebaliknya, bayi yang dilahirkan dapat memberikan toleransi yang baik terhadap persalinan, stress saat bersalin dan kehamilan lewat waktu, lahir vigorous serta periode neonatus dilalui dengan baik. Otot yang terlatih selama senam, akan memiliki kekuatan dan tonus otot yang baik, dan dipadu dengan teknik mengedan yang baik, maka persalinan akan lebih singkat. Dengan demikian, bayi akan lebih singkat tertahan di panggul bawah. ${ }^{14}$

Asfiksia neonatorum dapat merupakan kelanjutan dari kegawatan janin (fetal distress) intrauteri.Fetal distress adalah keadaan ketidakseimbangan antara kebutuhan $\mathrm{O}_{2}$ dan nutrisi janin sehingga menimbulkan perubahan metabolisme janin menuju metabolisme anaerob yang menyebabkan hasil akhir metabolismenya bukan lagi $\mathrm{CO}_{2}$. Asfiksia neonatorum disebabkan oleh banyak hal.Penyebab asfiksia adalah kondisi anemia maternal.Kondisi ini menyebabkan kemampuan transportasi $\mathrm{O}_{2}$ makin turun sehingga konsumsi $\mathrm{O}_{2}$ janin tidak terpenuhi.Metabolisme janin sebagian menuju metabolisme anaerob sehingga terjadi timbunan asam laktat dan piruvat, serta menimbulkan asidosis metabolik. Selain itu, kondisi syok dan hipotensi maternal dapat menyebabkan aliran darah menuju plasenta akan berkurang sehingga $\mathrm{O}_{2}$ dan nutrisi makin tidak seimbang untuk memenuhi kebutuhan metabolisme. ${ }^{2}$ Dalam penelitian ini, ibu bersalin dengan kondisi anemia dan syok atau hipotensi termasuk dalam kriteria eksklusi sehingga tidak diikutsertakan dalam penelitian ini.

Jika bayi mengalami asfiksia berat pada menit pertama dan pada menit kelima APGAR skor tetap <7, berhubungan dengan prevalensi gangguan syaraf dan rendahnya fungsi kognitif dimasa dewasa. ${ }^{13}$ Lamanya hipoksia selama proses kelahiran berhubungan dengan kejadian asidosis sesuai pengukuran oksimetri. $^{21}$

Penelitian $R C T$ tentang program latihan otot dasar panggul sekali seminggu menunjukan bahwa tidak ada perbedaan yang bermakna nilai APGAR antara kelompok eksperimen dan kelompok kontrol. Begitupula penelitian $R C T$ tentang program erobik di air, tidak menunjukan perbedaan statistik secara bermakna. ${ }^{19}$ Penelitian $R C T$ lainnya yang dilakukan di Spanyol juga menunjukan perbedaan yang bermakna antara kelompok yang melakukan senam atau latihan selama hamil dengan yang tidak senam $(p>0,05) .{ }^{16}$

Pada penelitian yang dilakukan di Bali, ditemukan $5,7 \%$ bayi mengalami asfiksia sedang di kelompok tidak senam. Sedangkan di kelompok senam semuanya lahir vigorous.Tidak dijumpai asfiksia berat pada 
kedua kelompok. Perbedaan nilai APGAR pada kedua kelompok ini tidak bermakna. ${ }^{14}$

Penelitian ini menemukan adanya kejadian asfiksia berat pada kelompok tidak senam. Kejadian asfiksia sedang, persentasi pada kelompok tidak senam lebih tinggi yaitu 40\% sedangkan kelompok senam hamil 3,3\%. Kejadian tidak asfiksia, persentasi tertinggi ada pada kelompok senam hamil yaitu 96,7\% dan kelompok tidak senam 53,3\%. Analisis statistik menunjukan perbedaan yang bermakna antara nilai APGAR menit pertama pada kelompok senam dan kelompok tidak senam $(p=0,001)$.

Sebuah penelitian yang dilakukan di Amerika, juga menemukan bahwa ibu hamil yang melakukan senam hamil, melahirkan bayi dengan APGAR skor yang normal baik pada menit pertama maupun menit kelima. ${ }^{20}$

\section{Simpulan}

Senam hamil efektif mempersingkat lama persalinan sejak fase aktif sampai dengan kelahiran bayi, maksimal 10 jam, menurunkan derajat robekan perineum/trauma jalan lahir sampai dengan derajat $<2$ dan menurunkan derajat asfiksia hingga $97 \%$ dan tidak terdapat bayi dengan asfiksia berat.

\section{Daftar Pustaka}

1. London ML, Ladewig PW, Ball JW, Bindler RCMG. Maternal-Newborn and Child Nursing. Family Centered Care. New Jersey: Pearson Education Inc; 2003. Hlm 142-58,309-30.

2. Manuaba IBG, Manuaba IAC, Manuaba IBGF. Pengantar Kuliah Obstetri. Jakarta: Penerbit Buku Kedokteran EGC; 2007. Hlm 136-303,324-38, 735-49,794-9,848

3. Pieter H.Z, Lubis N.L. Pengantar Psikologi Untuk Kebidanan. Jakarta: Kencana Prenada Media Group; 2010. Halaman 218,232-52.

4. Wulandari PY. Efektifitas Senam Hamil Sebagai Pelayanan Prenatal dalam Menurunkan Kecemasan Menghadapi Persalinan Pertama. Fakultas Psikologi Universitas Airlangga. Jurnal Insan (online serial). 2006;8(2). (diunduh 16 September 2011). Tersedia dari: http://journal.unair.ac.id/.

5. Morkved S, Bo K, Schei B, Salvesen KA. Pelvic Floor Muscle Training During Pregnancy to Prevent Urinary Incontinence: A Single-Blind Randomized Controlled Trial. American College of Obstetricians and Gynaecologist Journal Elsevier.2003;101(2).

6. Bo K, Fleten C, Nystad W. Effect of Antenatal Pelvic Floor Muscle Training on Labor and Birth. American College of Obstetricians and
Gynaecologist Journal. Lippincott Williams \& Wilkins. 2009;113(6).

7. Voldner N, Froslie KF, Haakstad LA, Bo K, Henriksen $\mathrm{T}$.

8. Saifuddin AB, Wiknjosastro GH, Birth Complications, overweight and physical inactivity. Acta Obstetric Gynecology Scand.Wiley Online Library. 2009;88(5):550-5.

9. Affandi B, Waspodo D, editor. Buku Panduan Praktis Pelayanan Kesehatan Maternal dan Neonatal. Jakarta: YBPSP bekerjasama dengan JNPKKR-POGI; 2002. Hlm 89,100-1,3479,495,501,536

10. Sastrawinata S, Martaadisoebrata D, Wirakusumah FF, Editor. Ilmu Kesehatan Reproduksi. Obstetri Patologi. Edisi 2. Jakarta: Penerbit Buku Kedokteran EGC; 2005. Hlm 1216.

11. Wiknyosastro G, dkk. Pelatihan Pelayanan Obstetri Neonatal Emergensi Dasar. Buku Acuan. Jakarta: Depkes RI bekerja sama dengan JNPK dan WHO; 2007. Hlm 6.1,9.1-9.3.

12. Dharmasetiawani N. Resusitasi Neonatus (Konsensus 2010). Artikel Ilmiah. 2013. Perinasia. (diunduh tanggal 16 Mei 2013). Tersedia dari: http://www.perinasia.com/post/116.

13. Oxorn H, Forte WR, Hakimi M. Ilmu Kebidanan: Patologi dan Fisiologi Persalinan. Human Labor and Birth. Yogyakarta: Yayasan Essentia Medica bekerjasama dengan CV Andi Offset; 2010. Hlm 441-57,525,603-18,660-2.

14. Ehrenstein V, Pedersen L, Grijota M, Nielsen GL, Rothman KJ, Sorensen HT. Association of APGAR score at five minutes with long-term neurologic disability and cognitive function in prevalence study of Danish conscripts. Research Article. BMC Pregnancy and Childbirth. 2009;9(14). Tersedia dari: http://www.biomedcentral.com/

15. Supriatmaja IPG, Suwardewa TGA. Pengaruh Senam Hamil Terhadap Persalinan Kala I dan Kala II di Bagian Ilmu Kebidanan dan Penyakit Kandungan FK UNUD/RS Sanglah Denpasar. Cermin Dunia Kedokteran. 2005; 146 Ginekologi (2): 48-51.

16. Primadi H. Senam Hamil. Bagian Obstetri dan Ginekologi FK Unpad. Bandung: Elstar Offset. Hlm: 1-8,21-56.

17. Barakat R, Pelaez M, Montejo R, Luaces M, Zakynthinaki M. Exercise During Pregnancy Improves Maternal Health Perception: a randomized Cotrolled Trial. Research Article. American Journal of Obstetrics and Gynecology. 2011;Vol.204: 402.e1-7. Tersedia dari: http://www.AJOG.org.

18. Notoatmodjo S. Metode Penelitian Kesehatan. Edisi Revisi. Jakarta: Rineka Cipta; 2010.

19. Hendriani N. Pengaruh Senam Hamil Terhadap Terjadinya Robekan Jalan lahir Pada Persalinan Primipara (Suatu Penelitian Di RSPAD Gatot Subroto Jakarta). Tesis. Bandung: Program Pascasarjana Unpad; 2008. Hlm: 21-5

20. Pivamik J.M, cs. Impact of Physical Activity during Pregnancy and Postpartum on Chronic 
Disease Risk. Special Communications. Roundtable Consensus Statement. Official Journal of the American College of Sport Medicine. 2006; 989-1006. (diunduh tanggal 27 Mei 2014). Tersedia dari: http://www.acsm-msse.org.

21. Perkins C.C.D., Pivarnik J.M., Paneth N, Stein A.D. Physical Activity and Fetal Growth During Pregnancy. American College of Obstetricians and Gynecologists. 2007;109(1):81-7. Tersedia dari: http://www.ACOG.org.

22. Laughon S.K, Berghella V, Reddy U.M, Sundaram R, Lu Z, Hoffman M.K. Neonatal and Maternal Outcome With Prolonged Second Stage of Labor. Original Research. American College of Obstetricians and Gynecologists. 2014;124(1): 57-67. Tersedia dari: http://www.ACOG.org.

23. Arikan GM, Scholz H.S, Haeusler MCH, Giuliani A, Weiss P.A.M. Low Fetal Oxygen Saturation at Birth and Acidosis. American College of
Obstetricians and Gynecologists. 2000;95(4): 565-71. Tersedia dari: $h t t p: / / w w w . A C O G . o r g$.

24. Walsh D. Evidence-Based Care for Normal Labour and Birth. A Guide For Midwive. New York: Routledge Taylor and Francis Group; 2007. Hlm: 109-10

25. Szumilewicz A, cs. Influence of Prenatal Physical Activity On The Course of Labor and Delivery According to the New Polish Standard for Perinatal Care. Review Article. Annals of Agricultural and Environment Medicine Journal. 2013;20(2):380-9. (diunduh tanggal 25 April 2014). Tersedia dari: http://www.aaem.pl.com.

26. Albers LL, Sedler KD, Bedrick EJ, Teaf D, Peralta P. Factors Related to Genital Tract Trauma in Normal Spotaneus Vaginal Births. Journal of Birth. 2006;33(2): 94-100. (diunduh tanggal 27 Mei 2014); tersedia dari: http://www.ncbi.com 